\title{
Organization citizenship behaviour, psychological empowerment and demographic characteristics: Teachers' perspective
}

\author{
Ammara Saleem ${ }^{1}$, Q. A. Nisar ${ }^{2}$, Asma Imran $^{3, *}$ \\ ${ }^{1}$ Department of Business Administration, Bahauddin Zakairiya University, Sahiwal, Pakistan \\ ${ }^{2}$ COMSTS Institute of Information Technology, Lahore, Pakistan \\ 3Department of Management Sciences, COMSATS Institute of Information Technology, Lahore, Pakistan
}

\section{A R T I C LE IN F O}

\section{Article history:}

Received 20 February 2017

Received in revised form

27 May 2017

Accepted 28 May 2017

Keywords:

Psychological empowerment

Organization citizenship behaviour

Demographic characteristics

University teachers

\begin{abstract}
A B S T R A C T
Several studies showed that the empowerment is pathway to organization citizenship behaviour (OCB) among teachers. Therefore this study focuses on investigating the relationship of psychological empowerment, demographic characteristics and organizational citizenship behaviour Participants of the survey were both from public and private sector universities of Punjab. Data was collected using the self-administered questionnaire. 213 questionnaires were distributed among the different 18 universities in Pakistan. We received 194 questionnaires from our respondents but only 180 was accurately filled and used for further analysis. Thus the response rate is $85 \%$. To determine relation between empowerment and OCB regression analysis was used. ANOVA analysis and independent sample t-test was used to examine the influence of demographic characteristics on OCB. Our findings show that psychological empowerment is significantly and strongly related to OCB. Furthermore, demographics are also found to be important to promote the OCB in university teachers, whereas tenure of the job is found to be significant predictor of employee empowerment.
\end{abstract}

(C) 2017 The Authors. Published by IASE. This is an open access article under the CC BY-NC-ND license (http://creativecommons.org/licenses/by-nc-nd/4.0/).

\section{Introduction}

Universities are the enlightening (educational) organizations which has very significant and sensitive mission. It needs teachers (faculty) with high voluntary and conscientious performance to achieve its objective in educating and training students (Bagheri et al., 2011).

Now days, teachers' role is extended over the one-way transmission of knowledge, but encompasses teaching learners how to learn, supplement their confidence, boosting their selfesteem, motivating them and managing an appropriate learning environment (Paxton, 2006). At university settings, however, interpersonal relationship need far stronger because of open and more communication between teachers and students. Students are mature enough and teachers can easily and openly communicate with them especially with post graduate students who are closely in touch with their supervisors (teachers)

\footnotetext{
* Corresponding Author.

Email Address: drasmaimran@ciitlahore.edu.pk (A. Imran) https://doi.org/10.21833/ijaas.2017.07.019

2313-626X/C) 2017 The Authors. Published by IASE.

This is an open access article under the CC BY-NC-ND license

(http://creativecommons.org/licenses/by-nc-nd/4.0/)
}

while doing their thesis (Sarkhosh and Rezaee, 2014).

In the higher education institutions (Universities), the most significant foundation for the determination of educational development and the academic excellence, is its workforce (teachers). Furthermore, universities too gradually become more conscious that faculty is the key person significantly contributing in accomplishing their mission. They also realized that like other organization volunteer behaviours are significant factor for organization (universities) survival and high performance (Khan et al., 2013).

In the literature, research on teacher's empowerment found and emerged in the late 1980s (Edwards et al., 2002). Teacher empowerment defined as a process whereby universities employees (teachers) and students build up the capability to take responsibility of their own growth and resolve their own problems as teacher empowerment contains enhanced prominence, more awareness and direct involvement to decision making (Maeroff, 1988). Rinehart and Short (1994) Categoried teacher empowerment into six dimensions. Theses dimensions includes decision making, career development, status, self-efficacy, autonomy and impact which are alike the four dimensions of 
Spreitzer psychological empowerment (Conger and Kanungo, 1988).

Empowerment is a process of enhancing employee feelings of self-efficacy within an organization and delegating authority to its employees (Conger and Kanungo, 1988). George and Brief (1992) studied the cognitive elements of empowerment. The four cognitions are impact, competence, meaningfulness and choice. "Meaning" is defined as purpose and personal approach to the work goal. It can be found in almost every task, job or organization. "Competence", second dimension of psychological empowerment is defined as an employee confidence to their capabilities to perform jobs well. "Self-determination", third dimension, is concerned with delegation of power to make their work related decisions. Self-determination exists when employees have some control over their work planning and scheduling like what to do, how to sequence work activities, what to start and what to hold etc. (Spector, 1986). "Impact", fourth and the last dimension, is the extent to which an employee can influence organization strategic decisions and concerns (Thomas and Velthouse, 1990).

Furthermore, the study also found that the four dimensions are interconnected and in joint will measure the empowerment constructs. The experience and result of empowerment becomes limited if any of the dimensions is missing (Spreitzer, 1995). Actually, the combination of the four dimensions imitates how an individual desires to structure and outline his work role or job (George and Brief, 1992).

Teachers' psychological empowerment is essential and significant for the effective transmission of knowledge, sharing of ideas and enhances student's intellectual and research abilities (Sarkhosh and Rezaee, 2014). Furthermore, Bogler and Somech (2004) found that teacher empowerment promotes the organization citizenship behaviour which contributes to the overall effectiveness of the teacher.

Organ (1988) defined organizational citizenship behavior (OCB) a self-instigated by organizational employees. Employees perform beyond their job requirements. They not only fulfilling their professional obligations and job but also taking voluntary actions in favour of organization like helping others, promoting company image, involving in decision making and offering advice (Organ, 1990). OCBs are normally discretionary and non-job related behaviours. These are less likely to be formally or explicitly rewarded but such behaviours shown by organization individuals found to be helpful in literature for long term success of organization (Podsakoff et al., 2000; Barroso et al., 2004). Moreover, Organ (1977) recognized OCB as a cognisant and self-directed behaviour resulting in improving business productivity and high returns. In that case, the individual employees go beyond their formal job obligations, provide voluntarily support, cooperate and confer with others.
The literature had observed some similarities and differences exist among the different forms of OCB constructs (Organ et al., 2006) similarities are defined as altruism, sportsmanship, conscientiousness, civic virtue and courtesy (Podsakoff et al., 2000).

Concept of "altruism" means disinterested and selfless concern for the well-being of others. It includes voluntary actions for helping the colleague with work problems. Altruism also includes application of thoughtful laws and investigation of the behaviours which prevent work problems for others. The showing of politeness in one's attitude and behaviour towards others, respect for rights and privileges of others, conference with those who may be pretentious by decision or action of the person, informing others before performing any important action can indicate "courtesy". "Conscientiousness" is the personality trait of being thorough, careful, or vigilant. It includes the behaviours which are expressed by the employee for performing duties beyond the determined requirements of the organizational role or what he is expected. "Civic virtue" refers to the positive involvement of employee in consulting with others before performing, giving notice before the decision making, and exchanging information with colleagues (Moghimi, 2013). "Sportsmanship" means an employee capacity to merrily adjust with workplace inflexibility and incompatibilities without complaining verbally or formally (Kernodle, 2007).

However, (Podsakoff et al., 2000) discussed some additional constructs of OCB, these are: "Helping behaviors", means show cooperation and/or helping others to overcome job related problems or challenges. It also encourages the other employees to be cooperative and concerned to their peers (Huey and Zaman, 2009).

"Self-development" the process by which a person's character or abilities, skills and knowledge are gradually developed to the benefit of the organization (George and Brief, 1992).

So, the higher institutes leaders and management need to observe and understand their faculty behaviours in order to increase the teaching quality and to contend successfully both domestically and internationally. Deans and heads could form the positive behaviour like organization commitment, job satisfaction, employees' retention, lower absenteeism and turnover and organization citizenship behavior of academics by empowering them (Bogler and Somech, 2004; Choong et al., 2011). Study by (Khan and Rashid, 2015), also suggested guidelines to help universities to promote OCB among academicians. They believe that in teachers OCB can play an important role in developing the students' personality and morality beyond delivering the best knowledge to them.

A study by Spreitzer (1995), found that empowered individuals recognize their job as significant and have sense of competence and an impact on their jobs. Such employees tend to be proactive and engage in volunteer behaviours in 
their job settings. These positive and volunteer behaviours are recognized as organization citizenship and organization commitment.

In academics, it has been observed that teachers having perception of exercising higher levels of empowerment are more confident, having better teaching skills and control over their work. They are more determined and have better work ideas. Moreover, several studies have found a positive relationship between psychological empowerment and employee performance (Wang and Zhang, 2012).

Findings relating to effect of psychological empowerment on job satisfaction and organizational citizen behaviour show that when the teachers have feeling of self-determination, competence, impact and meaning in workplace, they will have higher job satisfaction and higher tendency to express organizational citizen behaviour (Bogler and Somech, 2004).

Due to positive and favourable outcomes of empowerment, the subject has remained a focus area for many researchers during the past decade but the results are confusing (Sweetland and Hoy, 2000). This study aims to examine teacher empowerment in relation to most important outcome, organization citizenship- a key factor in their performance (Howell and Dorfman, 1986; Diefendorff et al., 2002). This study also aims to investigate:

1. Impact of psychological empowerment on the organization citizenship behaviour in University teachers

2. Access the impact of job tenure on Psychological empowerment in university teachers

3. Access the impact of demographic characteristics such as age, gender, qualification, job designation and tenure of the job on the level of OCB.

\section{Material and methods}

The above discussed literature leads to the development of following conceptual framework shown in Fig. 1.

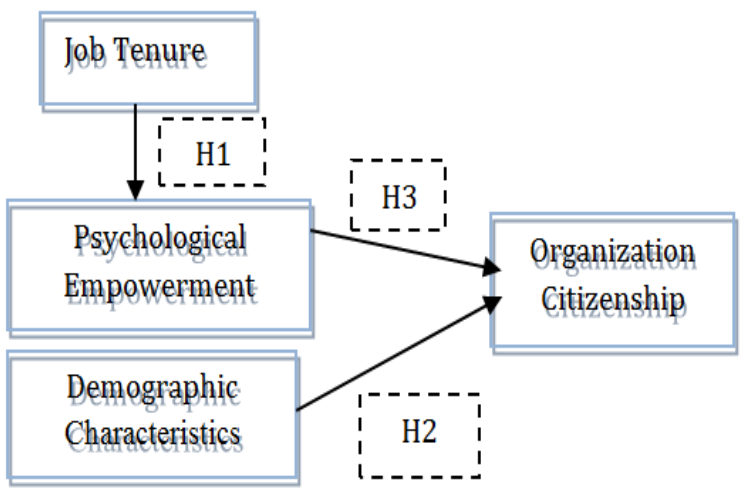

Fig. 1: The conceptual model of research

\subsection{Hypotheses}

Following hypotheses were established to access the relationship among studied variables:
Hypothesis1: Higher the job tenure, higher the perception of psychological empowerment

Hypothesis 2: Does any significant relation exist between OCB of university teachers and their demographic characteristics

Hypothesis3: Psychological empowerment is positively associated with OCB.

\subsection{Methodology}

This is the explanatory study, used the survey method to determine the relationship between university teachers' psychological empowerment and organizational citizenship behaviours. The study sample was selected from the HEC recognized universities list. The data was collected from the different 18 public and private universities of Pakistan by using non probability convenient sampling method. Out of 203 questionnaires distributed, 180 (89\%) were filled out and collected.

To measure employee empowerment, 16 item scale initially develop and validated by Spreitzer (1995) was used. To measure the OCB, scale by Podsakoff et al. 2000) was in this study. The thirty four items were scored using a Likert scale ranging from 1 to 5 . (1=strongly disagree to $5=$ strongly agree). The Cronbach's alpha for OCB is .824 and for employee empowerment is .77, which were considered good to very good (Hair et al., 2006).

The questionnaire contains two sections. The first section consists of demographics like gender, age, qualification and job information like job experience, no. of hours worked, job designation of the employees and the second section includes items to measure the five OCB dimensions and four psychological empowerment dimensions.

\section{Results and discussion}

Data were analyzed using independent sample ttest and one way AOVA and results are summarized in Table 1. Table 1 results indicate a significant relationship between job tenure and employee perception of psychological empowerment. Therefore results support the first hypothesis at 0.05 level of significance and this result is consistent with other studies in literature (Mearaj, 2010; Greasley et al., 2008). The results also partially support the hypothesis 2 .

\subsection{Gender}

The results supports the study hypothesis 2 that OCB is closely related to gender $(\alpha \leq 0.042, p<0.05)$ as found by Narang and Dwivedi (2010) in their study, that female teachers are more responsible and show greater concern towards student than male teachers but Rezaian (2006) examined that gender discrimination and lack of justice are the major reasons in discouraging the women to exhibit OCB. Some other studies in the literature found contradictory results that male employees exhibit 
more OCB than female employees (Rezaian, 2006; Mahnaz et al., 2013; Wanxian and Weiwu, 2007)

\subsection{Marital status}

The results $(\alpha-$ value is $.337, \mathrm{p}<0.05)$ doesn't support the study hypothesis 2 that perception of OCB behaviour vary with marital status and married teachers show higher level of OCB than unmarried teachers. This result is inconsistent with literature study by Mahnaz et al. (2013) and Robbins and Judge (2009) which observed that individual demographic characteristics such as age, gender, and marital status affect job behaviors like job satisfaction, turnover, OCB, involvement, performance, etc.

\subsection{Qualification}

The results given in Table 1 supports the hypotheses 2 those teachers with higher qualification are more engaged in volunteer behaviours like OCB $(\alpha \leq 0.001, \mathrm{p}<0.05)$.

Many researchers like Katz, 1964 and MacKenzie et al. (1993), found that the volunteer behavior of employees is for their own growth and development but Mahnaz et al. (2013) found that qualification is significantly associated with overall OCB not just self-development.

\subsection{Age}

Supports found for hypothesis 2 in the results of Table $1(\alpha \leq 0.011, p<0.05)$. Teachers who are in age of 46 or above are more committed to OCB than the young teachers.

The results are in accordance with the several studies in literature (Van Dyne et al., 1994).

\subsection{Job position}

The results also shows strong association between OCB and job designation $(\alpha \leq 0.024, p<0.05)$ and supports the hypothesis 2 .

Organizational power and freedom of choice inherited from the job position influence the employee commitment level which ultimately associated with OCB. This result is also consistent with previous study results (Hrebiniak and Alutto, 1972)

\subsection{Job experience}

Among the five job experience categories, employees with more experience demonstrate the higher level of OCB $(\alpha \leq 0.000, \quad p<0.05)$ and supported by the findings of Meyer and Allen (1984) and Mearaj (2010).

Table 1: The demographic characteristics of the subjects

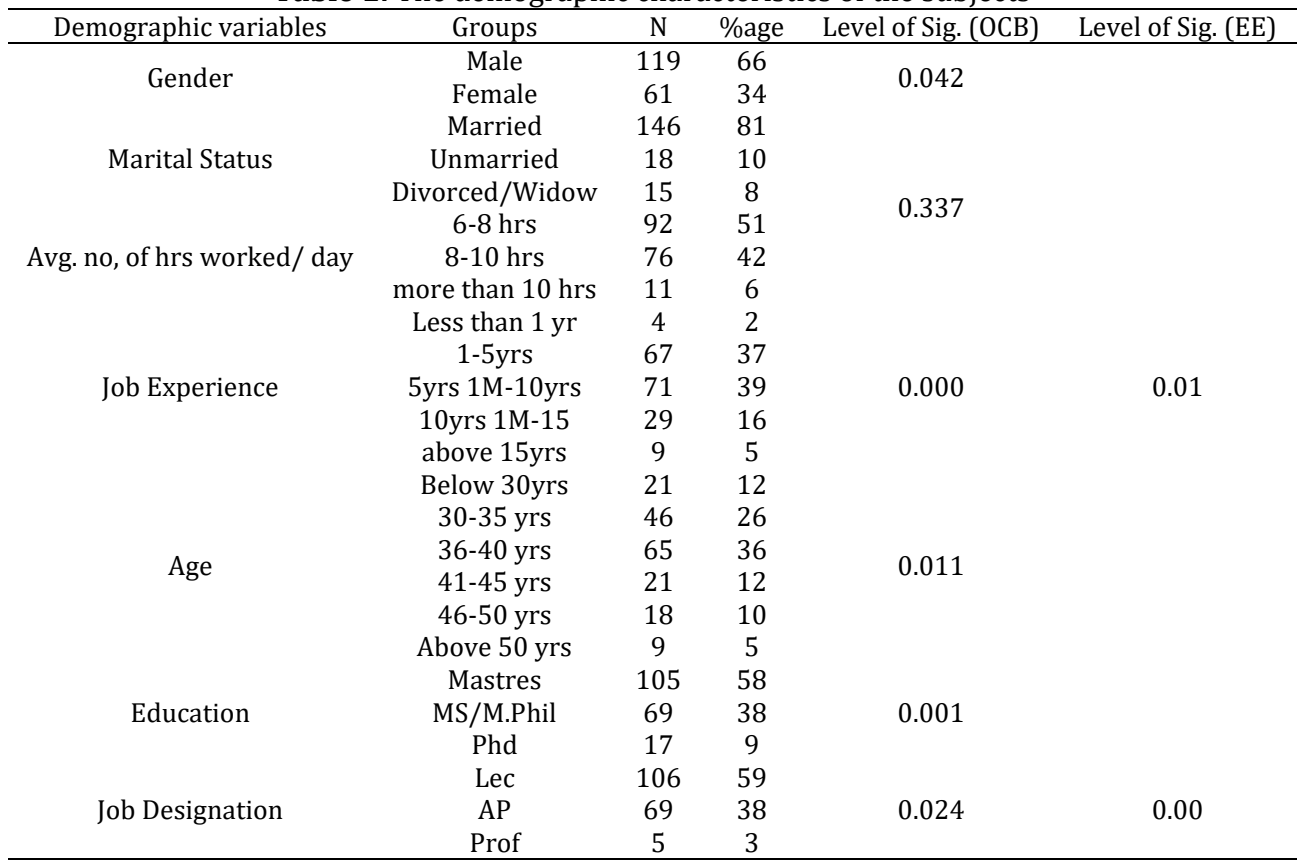

Table 2, summarizes the regression analyses results. Regression analysis was run to test the hypotheses 3.nt on OCB. According to model summary, the independent variable employee empowerments together explain $42.3 \%$ of the variance ( $\mathrm{R}$ Square) with dependent variable organization citizenship behaviour, which is highly significant, as indicated by the p-value (.000) which in all case is less than .05. The regression equation for OCB is
Emp. OCB $=0.296+0.708$ (emp. Empw).

Linear regression analysis results indicates a positive significant relationship between employee overall perception of psychological empowerment and organizational citizenship behaviour (OCB) as found by other researchers in the literature (Bhatnagar and Sandhu, 2005; Wat and Shaffer, 2005, Jiang and Fu, 2011; Jin-Liang and Hai-Zhen, 2012; Karavardar, 2014). 
Table 2: Coefficients

\begin{tabular}{cccccc}
\hline \multirow{2}{*}{ Model } & \multicolumn{2}{c}{ Unstandardized Coefficients } & \multirow{2}{*}{ T } & \multirow{2}{*}{ Sig. } \\
\cline { 3 - 4 } & & $\mathrm{B}$ & Std. Error & & \\
\hline \multirow{2}{*}{1} & (Constant) & .296 & .131 & 2.251 & .026 \\
& Empw & .708 & .062 & 11.42 & .000 \\
\hline
\end{tabular}

\section{Conclusion}

The study results confirmed the hypothesized model. Moreover, the model is best in explaining the influence of empowerment on organizational citizenship behaviour. The findings which were obtained from this study showed that higher the feeling of psychological empowerment in their work, higher tendency they show to express organizational citizenship behaviors. This conclusion is accordance with findings of other researcher in the literature (Abazeed, 2009; Nezakati et al., 2010). All the researchers mentioned in this study also indicated that those managers who feel psychological empowerment show higher organizational citizenship behaviour. This study also concludes that without empowering their faculties, universities can never be successful in accomplishing their mission.

This study valuably contributions to the literature. First of all, this study is the initiative step to the studies of higher education institutions in a developing country which not only examine the impact of employee empowerment on organizational citizenship behaviour but also examine the impact of different demographic characteristics on OCB and employee empowerment. Demographic characteristics except marital status like gender, age, job designation and job experience are significantly associated with OCB as discussed by other studies (Premsagunnism, 2009; Mahnaz et al., 2013). This study results also signifies that teacher empowerment is becoming vital for teacher's high performance. This present study's results would be beneficial in motivating both the teachers and directors to provide opportunities to their faculty to improve their qualification.

\section{Limitations and recommendations}

This study has some limitations. The study sample was taken from the universities of the Punjab province only. Therefore, results of study may not be generalized to other provinces. Another limitation of this study was the questionnaires' distribution. Questionnaires were distributed among the faculty members of different departments. All questionnaires were self-reported, which may have contributed toward the common method bias. Furthermore, this study only examined the combined and direct impact of psychological empowerment on overall OCB.

Regarding the limitations and findings of the study, this study suggests some recommendations for the future research. Firstly, this study must be examined in schools and colleges to determine whether the results presented here reflect the general situation of teachers on all levels. Secondly, this study can also be extended to determine the association of different dimensions of employee empowerment with the different dimensions of OCB. Furthermore, a study on the comparison of the perception of employee empowerment and OCB in the public and private sector universities can be done.

Lastly, future studies may be conducted to examine the influence on teachers' psychological empowerment on other organizational behaviours like job involvement, employee engagement, turn over, etc.

\section{References}

Abazeed R (2009). The effect of psychological empowerment on citizenship behavior of employees in social security corporation in Jordan. An-Najah University Journal for Research, 24(2): 493-519.

Bagheri G, Matin HZ, and Amighi F (2011). The relationship between empowerment and organizational citizenship behavior of the pedagogical organization employees. Iranian Journal of Management Studies, 4(2): 53-62.

Barroso CC, Martín Armario E, and Martín Ruiz D (2004). The influence of employee organizational citizenship behavior on customer loyalty. International Journal of Service Industry Management, 15(1): 27-53.

Bhatnagar J and Sandhu S (2005). Psychological empowerment and organisational citizenship behaviour (OCB) in 'IT' managers: A talent retention tool. Indian Journal of Industrial Relations, 40(4): 449-469.

Bogler R and Somech A (2004). Influence of teacher empowerment on teachers' organizational commitment, professional commitment and organizational citizenship behavior in schools. Teaching and Teacher Education, 20(3): 277-289.

Choong YO, Wong KL, and Lau TC (2011). Psychological empowerment and organizational commitment in the Malaysian private higher education institutions: A review and research agenda. Academic Research International, 1(3): 236245.

Conger JA and Kanungo RN (1988). The empowerment process: Integrating theory and practice. Academy of Management Review, 13(3): 471-482.

Diefendorff JM, Brown DJ, Kamin AM, and Lord RG (2002). Examining the roles of job involvement and work centrality in predicting organizational citizenship behaviors and job performance. Journal of Organizational Behavior, 23(1): 93108.

Edwards JL, Green KE, and Lyons CA (2002). Personal empowerment, efficacy, and environmental characteristics. Journal of Educational Administration, 40(1): 67-86.

George JM and Brief AP (1992). Feeling good-doing good: A conceptual analysis of the mood at work-organizational spontaneity relationship. Psychological Bulletin, 112(2): 310329.

Greasley K, Bryman A, Dainty A, Price A, Naismith N, and Soetanto $R$ (2008). Understanding empowerment from an employee perspective: what does it mean and do they want it?. Team Performance Management: An International Journal, 14(1/2): 39-55.

Hair JF, Black WC, Babin BJ, Anderson RE, and Tatham RL (2006). Multivariate data analysis. 6th Edition, Pearson Prentice Hall, Upper Saddle River, USA.

Howell JP and Dorfman PW (1986). Leadership and substitutes for leadership among professional and nonprofessional workers. The Journal of Applied Behavioral Science, 22(1): 29-46. 
Hrebiniak LG and Alutto JA (1972). Personal and role-related factors in the development of organizational commitment. Administrative Science Quarterly, 17(4): 555-573.

Huey YL and Zaman BAK (2009). The moderating effects of organizational culture on the relationships between leadership behaviour and organizational commitment and between organizational commitment and job satisfaction and performance. Leadership and Organization Development Journal, 30(1): 53-86.

Jiang X and Fu Q (2011). Relationship between universities organizational culture, teachers' psychological empowerment and organizational citizenship behavior. In the $4^{\text {th }}$ International Joint Conference on Computational Sciences and Optimization, IEEE, Yunnan, China: 699-703. https://doi.org/10.1109/CSO.2011.217

Jin-Liang W and Hai-Zhen W (2012). The influences of psychological empowerment on work attitude and behavior in Chinese organizations. African Journal of Business Management, 6(30): 8938-8947.

Karavardar G (2014). Perceived organizational support, psychological empowerment, organizational citizenship behavior, job performance and job embeddedness: A research on the fast food industry in Istanbul, Turkey. International Journal of Business and Management, 9(4): 131-139.

Katz D (1964). The motivational basis of organizational behavior. Systems Research and Behavioral Science, 9(2): 131-146.

Kernodle TA (2007). Antecedents and consequences of organizational citizenship behavior: A hierarchical linear modeling study. Ph.D. Dissertation, Touro University International, Cypress, USA.

Khan I, Khan F, Khan H, Nawaz A, and Yar NB (2013). Determining the demographic impacts on the organizational commitment of academicians in the HEIs of DCs like Pakistan. European Journal of Sustainable Development, 2(4): 117-130

Khan SK and Rashid MZA (2015). The mediating effect of organizational commitment in the organizational culture, leadership and organizational justice relationship with organizational citizenship behavior: A study of academicians in private higher learning institutions in Malaysia. International Journal of Recent Advances in Organizational Behaviour and Decision Sciences (IJRAOB): An Online International Research Journal, 1(2): 335-359.

MacKenzi SB, Podsakoff PM, and Fetter R (1993). The impact of organizational citizenship behavior on evaluations of salesperson performance. The Journal of Marketing, 57(1): 70-80.

Maeroff GI (1988). The empowerment of teachers. overcoming the crisis of confidence. Teachers College Press, New York, USA.

Mahnaz MA, Mehdi M, Jafar KM, and Abbolghasem P (2013). The effect of demographic characteristics on organizational citizenship behavior in the selected teaching hospitals in Tehran. African Journal of Business Management, 7(34): 3324-3331.

Mearaj A (2010) Organizational citizenship behavior (OCB): Inside Bahraini Organizations. Ph.D. Dissertation, Open University Malaysia, Kuala Lumpur, Malaysia.

Meyer JP and Allen NJ (1984). Testing the" side-bet theory" of organizational commitment: Some methodological considerations. Journal of Applied Psychology, 69(3): 372378.

Moghimi M (2013). The mediating effects of psychological empowerment and job satisfaction in the relationship between transformational leadership and organizational citizen behavior. Journal of Basic and Applied Scientific Research, 3(5): 237-244.

Narang R and Dwivedi A (2010). Managing the job satisfaction of knowledge workers: An empirical investigation. Asia Pacific Journal of Business and Management, 1(1): 1-14.
Nezakati H, Asgari O, Karimi F, and Kohzadi V (2010). Fostering organizational citizenship behavior (OCB) through human resources empowerment (HRE). World Journal of Management, 2(3): 47-64.

Organ DW (1977). A reappraisal and reinterpretation of the satisfaction-causes-performance hypothesis. Academy of management Review, 2(1): 46-53.

Organ DW (1988). Organizational citizenship behavior: The good soldier syndrome. Lexington Books/DC Heath and Com, Lexington, USA.

Organ DW (1990). The motivational basis of organizational citizenship behavior. Research in Organizational Behavior, 12(1): 43-72

Organ DW, Podsakoff PM, and MacKenzie SB (2006). Organizational citizenship behavior: Its nature, antecedents, and consequences. Sage Publications, Thousand Oaks, USA.

Paxton P (2006). Building empowered students: The perennial challenge for university teachers. In the EDU-COM International Conference, Edith Cowan University, Western Australia in Association with Khon Kaen University, Thailand and Bansomdejchaopraya Rajabhat University, Bangkok, Thailand. Available online at: http://ro.ecu.edu.au/cgi/ viewcontent.cgi?article=1094\&context=ceducom

Podsakoff PM, MacKenzie SB, Paine JB, and Bachrach DG (2000). Organizational citizenship behaviors: A critical review of the theoretical and empirical literature and suggestions for future research. Journal of Management, 26(3): 513-563.

Premsagunnism N (2009). Relationship of personal factors and organizational citizenship behavior. Journal of Education, 30(12): 177-99.

Rezaian A (2006). Basics of organizational behaviours. Management Publication, Tehran University, Tehran, Iran.

Rinehart J and Short PM (1994). Job satisfaction and empowerment among teacher leaders, reading recovery teachers, and regular classroom teachers. Academic Journal Article Education, 114(4): 570-580.

Robbins SP and Judge TA (2009) Organizational behavior. $13^{\text {th }}$ ed., Prentice Hall, Upper Saddle River, USA.

Sarkhosh M and Rezaee AA (2014). How does university teachers' emotional intelligence relate to their self-efficacy beliefs. Porta Linguarum: Revista Internacional De Didáctica De Las Lenguas Extranjeras, (21): 85-100.

Spector PE (1986). Perceived control by employees: A metaanalysis of studies concerning autonomy and participation at work. Human Relations, 39(11): 1005-1016

Spreitzer GM (1995). Psychological empowerment in the workplace: Dimensions, measurement, and validation. Academy of Management Journal, 38(5): 1442-1465.

Sweetland SR and Hoy WK (2000). School characteristics and educational outcomes: Toward an organizational model of student achievement in middle schools. Educational Administration Quarterly, 36(5): 703-729.

Thomas KW and Velthouse BA (1990). Cognitive elements of empowerment: An interpretive model of intrinsic task motivation. Academy of Management Review, 15(4): 666-681.

Van Dyne L, Graham JW, and Dienesch RM (1994). Organizational citizenship behavior: Construct redefinition, measurement, and validation. Academy of Management Journal, 37(4): 765802.

Wang JL and Zhang DJ (2012). An exploratory investigation on psychological empowerment among Chinese Teachers. Advances in Psychology Study, 1(3): 13-21.

Wanxian L and Weiwu W (2007). A demographic study on citizenship behavior as in-role orientation. Personality and Individual Differences, 42(2): 225-234. 
Wat D and Shaffer MA (2005). Equity and relationship quality influences on organizational citizenship behaviors: The mediating role of trust in the supervisor and empowerment. Personnel Review, 34(4): 406-422. 